\title{
A Novel RING-H2 Motif Protein Downregulated by Axotomy: Its Characteristic Localization at the Postsynaptic Density of Axosomatic Synapse
}

\author{
Manabu Nakayama, ${ }^{a}$ Toshihiko Miyake, Yoshinari Gahara, Osamu Ohara, ${ }^{b}$ and Tadahisa Kitamura \\ Shionogi Research Laboratories, Shionogi and Co., Ltd., 5-12-4 Sagisu, Fukushima-ku, Osaka 553, Japan
}

\begin{abstract}
Axonal Injury and its repair are common and basic neuropathological processes in the CNS, and are composed of a complex of events in a molecular term. In order to get a comprehensive understanding of these processes, we isolated several known and unknown genes which were upor downregulated in the facial nucleus after transection of the facial nerve by a subtractive/differential screening. Among them, we focus on one downregulated gene, named Neurodap1, because this gene encodes a novel protein carrying the RING-H2 sequence motif categorized in the zinc finger family. Immunoelectron microscopic analysis revealed that the protein encoded by Neurodap1, Neurodap1, was distributed mainly on the cytoplasmic side of the membranes constituting endoplasmic reticulum and Golgi apparatus, supporting the notion of a previously postulated function of RING-H2 motif proteins, that is, involvement in the protein sorting machinery. More interestingly, Neurodap1 was also bound to the postsynaptic density (PSD) region of axosomatic synapses. This fact suggests that Neurodap1 is associated with a specific system sorting proteins to PSD. Therefore, Neurodap1, a newly identified protein as an axotomy-suppressed gene product, might play a significant role in synaptic communication and plasticity through the control of the formation of PSD for maintaining vital functions of nerve cells.
\end{abstract}

[Key words: Neurodap1, axotomy, facial nerve, subtractive/differential screening, the RING-H2 motif, postsynaptic density]

Axonal injury followed by retrograde degeneration of the affected nerve cells or by regeneration of axons is considered to be a common process occurring in the CNS and PNS. A comprehensive understanding of this process on a molecular basis would give us a deep insight into the repair process in the nervous system or the pathogenesis of degenerative diseases of the nerve cells. For an approach toward this end, axotomy of rat facial nerve provides us a conventional experimental model,

\footnotetext{
Received Dec. 12, 1994; revised Feb. 13, 1995; accepted Feb. 28, 1995.

This work is, in part, supported by Japan Health Science Foundation and Grant-in-Aid for Scientific Research on Priority Areas, Ministry of Education, Science and Culture, Japan.

Correspondence should be addressed to Dr. Tadahisa Kitamura at the above address.

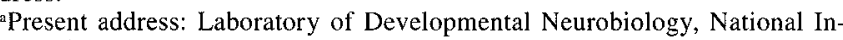
stitute of Child IIealth and IIuman Development, National Institute of IIealth, Building 49, Room 5A-38, Bethesda, MD 20892.

Present address: Laboratory of DNA Technology, Kazusa DNA Research Institute, 1532-3 Yana-uchino, Kisarazu, Chiba 292, Japan.

Copyright (C) 1995 Society for Neuroscience $0270-6474 / 95 / 155238-11 \$ 05.00 / 0$
}

where the events occurring in and around the affected nerve cell bodies subsequent to the axotomy can be investigated in a way separated from those directly evoked by the surgical procedure itself, because transection-site of the axons is far from the cell body of the affected nerve cells.

Apart from central chromatolysis in the affected nerve cells, a series of glial reactions has been reported to take place at the corresponding nucleus following axotomy of the facial nerve. First, the astrocytes show increased levels of glial fibrillary acidic protein (Kitamura and Fujita, 1985; Graeber and Kreutzberg, 1986). Second, microglia become activated and proliferate, while astrocytes do not undergo mitosis (Kitamura and Fujita, 1985; Graeber et al., 1988). Third, perineuronal microglia appear to intrude their processes into the synaptic clefts and to push aside the synaptic terminals from the surface of neuronal cell body and main dendrites (Blinzinger and Kreutzberg, 1968).

In spite of these phenomenological observations, little is known about the molecular biological events that occur in the area around the nerve cell bodies in response to axotomy. A very small number of genes, including those of GAP-43, $\alpha$-tubulin, neurofilaments, GFAP, NGF receptor, and amyloid $\beta$ protein precursor ( $\beta A P P)$, are already reported to change its expression levels after axotomy (Basi et al., 1987; Miller et al., 1989; Kitamura and Watanabe, 1990; Kitamura, 1991; Kitamura et al., 1991; Saika et al., 1991; Tetzlaff et al., 1991; Chiu et al., 1993; Solà et al., 1993). However, these identified genes must constitute only a part of the genes modulated by axotomy, because they are inductively assigned simply from their known biological functions. Since there must be many unknown genes expressed in the facial nucleus, it is very likely that some of these unknown genes play an important role in the events following axotomy.

For identification of genes affected by axotomy, we adopted a cloning strategy termed subtractive/differential screening in this study, which allowed us to detect genes affected by axotomy of the facial nerve without any a priori knowledge on their gene functions. We could successfully isolate some axotomy-associated genes by this cloning strategy. Here, we focus on one of these isolated genes, which was down-regulated by axotomy. This gene encodes a novel protein, named Neurodap l, carrying a characteristic sequence motif, the RING-H2 motif, which is categorized in the zinc finger family. We discuss the possible function of Neurodap1 on the basis of its characteristic intracellular localization.

\section{Materials and Methods}

Animals and surgical procedures. Adult male Sprague Dawley rats (6 8 week old) were uised. The animals were anesthetized with sodium 

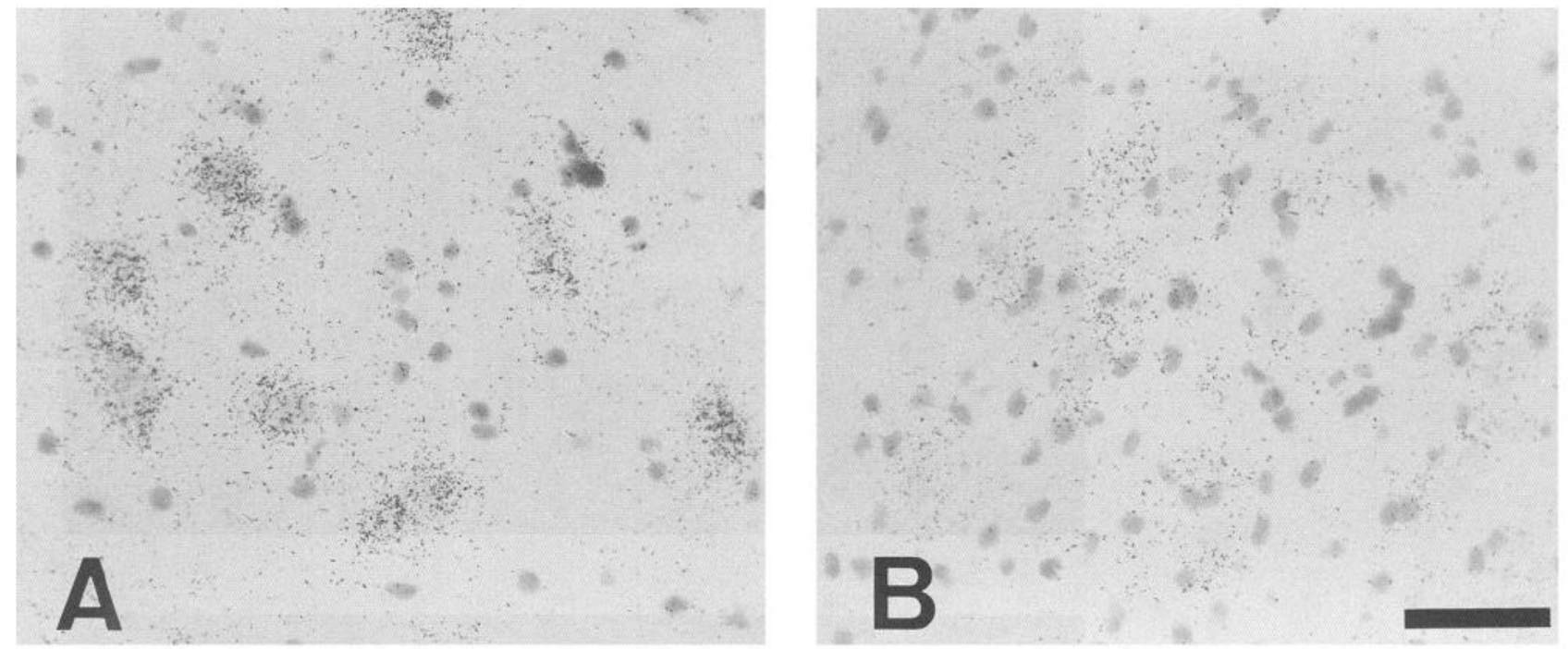

Figure 1. Bright-field photomicrographs showing the localization of Neurodap1 mRNA in the facial nucleus of the unoperated side $(A)$ and of the operated side $(B) 7 \mathrm{~d}$ after axotomy. Cells expressing the Neurodapl signal are large in size and are considered to be motoneurons. Scale bar, $50 \mu \mathrm{m}$.

pentobarbital, and the left facial nerve was transected at the level of stylomastoid foramen. The animals were sacrificed under pentobarbital or ether anesthesia $1,3,7,9$, and $14 \mathrm{~d}$ after axotomy, and their brain tissue was processed for molecular analysis or morphological studies.

$R N A$ preparation. Forty rats received axotomy of the left facial nerve and were sacrificed by decapitation under ether anesthesia $24 \mathrm{hr}$ thereafter. Brainstem was gently cut with a razor blade so that the bilateral facial nuclei could be contained within a $1.5 \mathrm{~mm}$ thick single slice, and then, each facial nucleus was punched out with a 15 gauge stainless steel bore tubing (Yu, 1989). Excised brain tissue containing the left or right facial nucleus was processed for RNA extraction according to the Chomczynski and Sacchi method (Chomczynski and Sacchi, 1987).

Construction of cDNA library. Directional cDNA libraries were constructed from $30-60 \mu \mathrm{g}$ of total RNA obtained from the left or right facial nuclei. For this purpose, we used a cDNA construction kit (GIBCO-Bethesda Research Labs, Gaithersberg, MD) according to the supplier's instructions with following minor modifications: oligomer A [5'GACTAGTCAAAGCGGCCGCGAGCTC $\left(\mathrm{T}_{20}-3^{\prime}\right]$ was used as an adapter primer for first-strand cDNA synthesis and oligomers $\mathrm{B}$ and $\mathrm{C}$ (5'-CGCGTCCGAGCTCGGC-3' and 5'-GCCGAGCT CGGA-3', respectively) were used as adapters for cDNA insertion into a pBluescript SK- vector (Stratagene, La Jolla, CA).

Subtractive/differential hybridization. Subtractive hybridization was performed essentially as described in the previous papers (Rubenstein et al., 1990; Swaroop et al., 1991), and briefly as follows. For getting genes upregulated by axotomy, the cDNA library of the left (operated) facial nuclei was used to generate single-stranded (ss) circular DNA with helper phage M13KO7. The double-stranded (ds) plasmid DNA prepared from the cDNA library of the right (unoperated) facial nuclei was used to synthesize biotinylated run-off transcripts with biotinylated UTP (Enzo Biochem, NY). Typically, $0.4 \mu \mathrm{g}$ of ss DNA from the operated library was annealed to $40 \mu \mathrm{g}$ of biotinylated RNA from the unoperated cDNA library in $10 \mu \mathrm{l}$ of hybridization buffer [ $0.5 \mathrm{M}$ sodium phosphate (pH 7.2), $10 \mathrm{~mm}$ EDTA and $0.1 \%$ SDS] at $65^{\circ} \mathrm{C}$ for $16 \mathrm{hr}$. Then, the biotinylated RNA and the DNA hybridized to this biotinylated RNA was removed by adding streptavidin (GIBCO BRL), and extracted by phenol/chloroform (Rubenstein et al., 1990). The ss DNA remaining after the streptavidin-phenol treatment was converted to ds DNA using Sequenase (United States Biochemical, Cleveland, $\mathrm{OH}$ ) and primer D [5'-GCCGCGAGCTC(T)10-3']. The obtained dsDNA was then transfected into Escherichia coli (E. coli) DH10B cells (GIBCO BRL) by electrotransform method. An insert cDNA in each clone from the subtracted library was amplified by PCR with oligomers B and D. Each PCR product (about $0.2 \mathrm{mg}$ ) was spotted onto duplicate nylon filters with a 96 well dot blot apparatus. Differential screening of the subtracted library was performed with random-primed ${ }^{32} \mathrm{P}$-labeled cDNA probes from the operated or unoperated facial nuclei. For getting downregu- lated genes, similar process was carried out, using the cDNA library of the right (unoperated) facial nuclei for synthesis of single-stranded (ss) circular DNA and that of the left (operated) facial nuclei for doublestranded (ds) plasmid DNA.

DNA sequencing. A full-length cDNA of Neurodapl (pfull223) was isolated from the right (unoperated) facial nucleus cDNA library by colony hybridization. DNA sequencing by the dideoxy-chain termination method was performed using a Sequenase kit (United States Biochemical) under primer walking and nested deletion strategies as instructed by the manufacturer. The complete $4.8 \mathrm{kbp}$ of Neurodapl cDNA was sequenced on both strands. Homology searches were performed against GenBank (release number 79)/EMBL (release number 35)/DDBJ (release number 15) nucleic acid data bases and NBRF/Swiss pROT/PIR protein data bases using homology comparison programs, FASTA and TFASTA, respectively (Pearson and Lipman, 1988). A search for protein sequence motifs was carried out with the PROSITE program (Bairoch, 1991).

In vitro transcription-translation assay. In vitro transcription-translation coupled assays were performed with a TNT T7-Reticulocyte lysate system (Promega, Madison, WI) as instructed by the manufacturer using $2 \mu \mathrm{g}$ each of plasmids of interest.

In situ hybridization. The animals sacrificed 3, 7, and $14 \mathrm{~d}$ after axotomy were used for in situ hybridization. Frozen sections containing the bilateral facial nuclei were cut at $5 \mu \mathrm{m}$ on a cryostat, and they were fixed with $4 \%$ paraformaldehyde in PBS. In situ hybridization was performed using isotope- or digoxigenin-labeled RNA probes, essentially as described in the previous paper (Nakayama et at., 1994).

Isotope-labeled RNA probes were prepared using T3 or T7 RNA polymerase with $\alpha-{ }^{35} \mathrm{~S}$-UTP $(800 \mathrm{Ci} / \mathrm{mmol}$, Amersham, Buckinghamshire, UK). The hybridization was carried out under the condition of 5 $\times 10^{7} \mathrm{cpm} / \mathrm{ml} \mathrm{RNA}$ probe at $55^{\circ} \mathrm{C}$ for $16 \mathrm{hr}$. After washing with 0.1 $\times$ SSC for $30 \mathrm{~min}$ at $60^{\circ} \mathrm{C}$, the sections were subjected to treatment with ribonuclease A (Sigma, St. Louis, MO, USA) $\left(30 \mathrm{~min}\right.$ at $\left.37^{\circ} \mathrm{C}\right)$. The sections were then coated with nuclear emulsion (Kodak NTB2, Eastman Kodak), and were exposed in a dark box at $4^{\circ} \mathrm{C}$ for $7 \mathrm{~d}$. After development, the sections were stained with hematoxylin-eosin, and then, observed under a dark- or bright-field light microscope (Zeiss Axiophoto, Karl Zeiss, Germany).

Digoxigenin-labeled RNA probes were prepared using DIG RNA Labeling Kit (Boehringer Mannheim GmbH, Mannheim, Germany). After hybridization, digoxigenin-labeled Neurodapl mRNA was detected with alkaline phosphatase-conjugated Fab fragments of sheep anti-digoxigenin antibody (Boehringer Mannheim $\mathrm{GmbH}$ ) [1:500 dilution by $100 \mathrm{~mm}$ Tris- $\mathrm{HCl}(\mathrm{pH} 7.5)+150 \mathrm{~mm} \mathrm{NaCl}]$ and BCIP/NBT Phosphatase Substrate System (GIBCO BRL), according to the procedure described by Springer et al. (1991).

Production of antibody against glutathione S-transferase (GST)-fused 

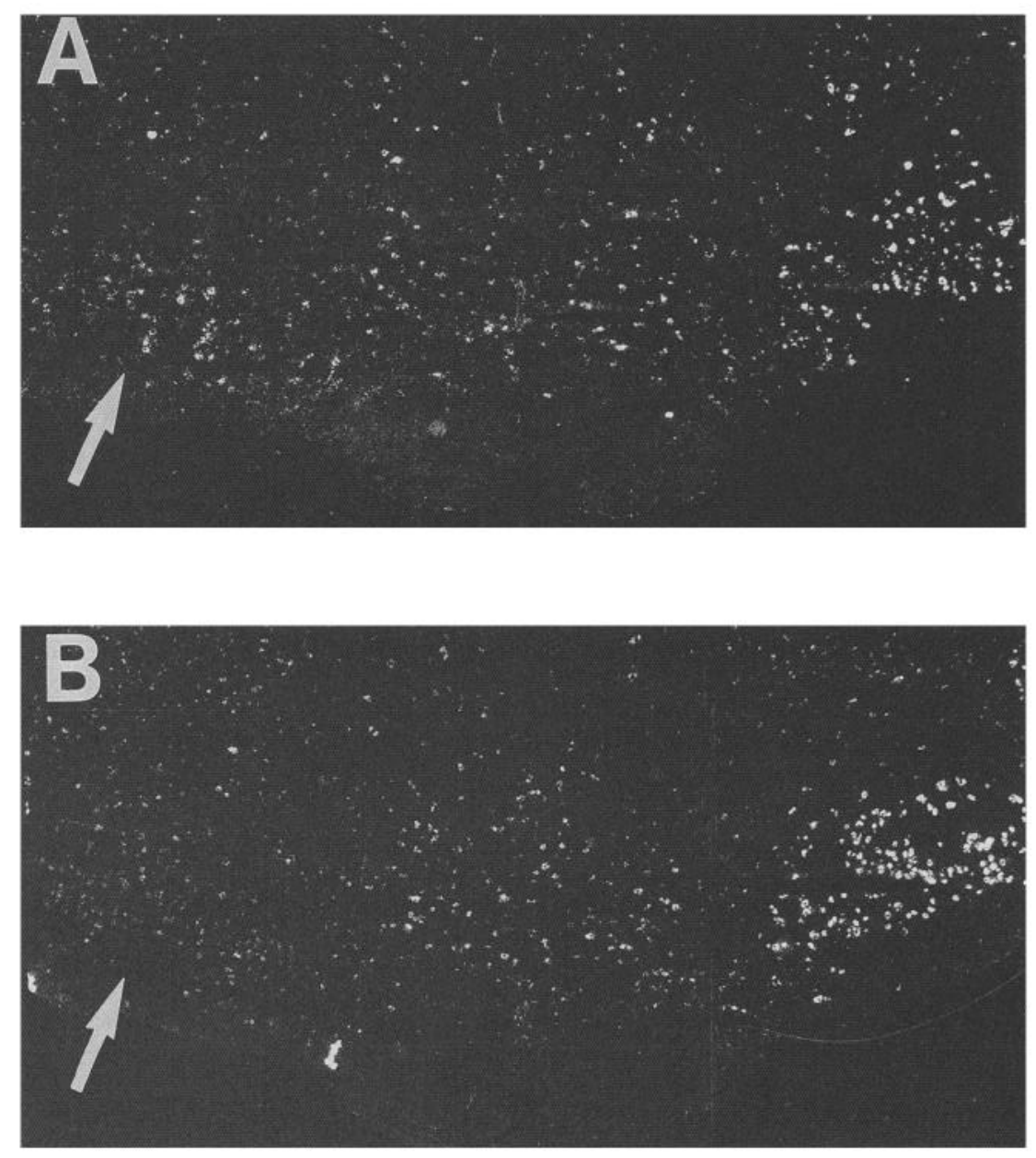

Figure 2. Dark-field photomicrographs showing the expression of Neurodap1 mRNA $3 \mathrm{~d}(A), 7 \mathrm{~d}(B)$, and 14 $\mathrm{d}(C)$ after facial nerve axotomy. $A r$ rows indicate the left facial nucleus (the side of axotomy). Neurodap1 mRNA level in the facial motoneurons is decreased following axotomy. Scale bar, $1000 \mu \mathrm{m}$.

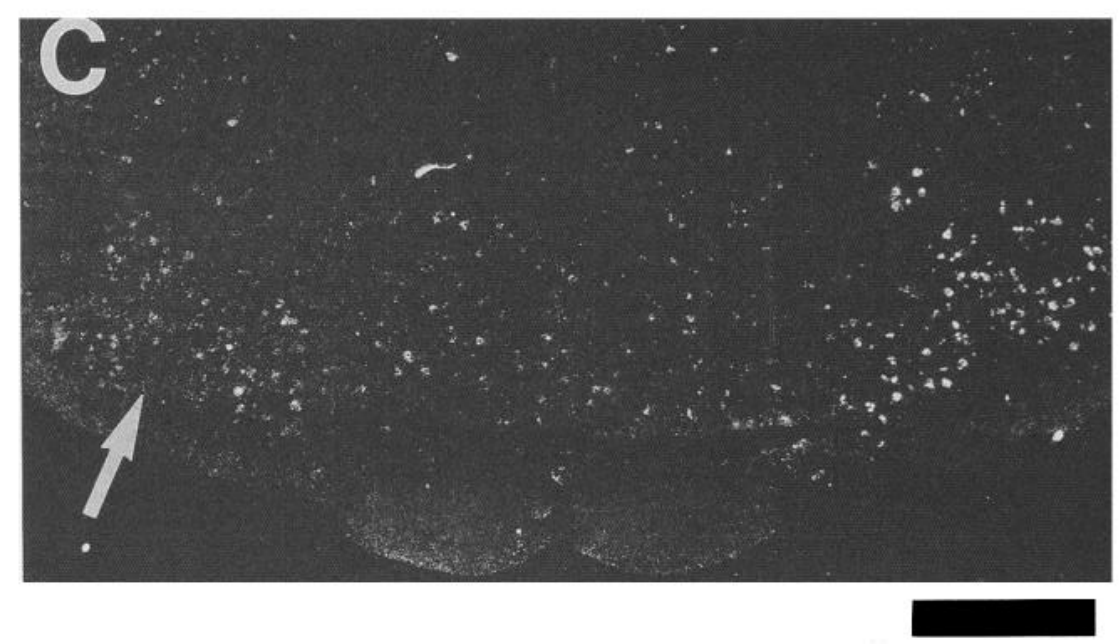

Figure 3. Distribution of Neurodap1 mRNA and protein by in situ hybridization and immunohistochemistry. In situ hybridization was performed on sections of the cerebellum $(A)$, hippocampus $(B)$, and cerebral cortex $(C)$ using digoxigenin-labeled antisense RNA probe of the Neurodap1 gene. The sections were lightly stained with hematoxylin-eosin. Immunohistochemistry was performed on sections of the cerebellum $(D)$, hippocampus $(E)$, and cerebral cortex $(F)$ using the purified anti-Neurodap1 protein antibody. Scale bars, $100 \mu \mathrm{m}$. 

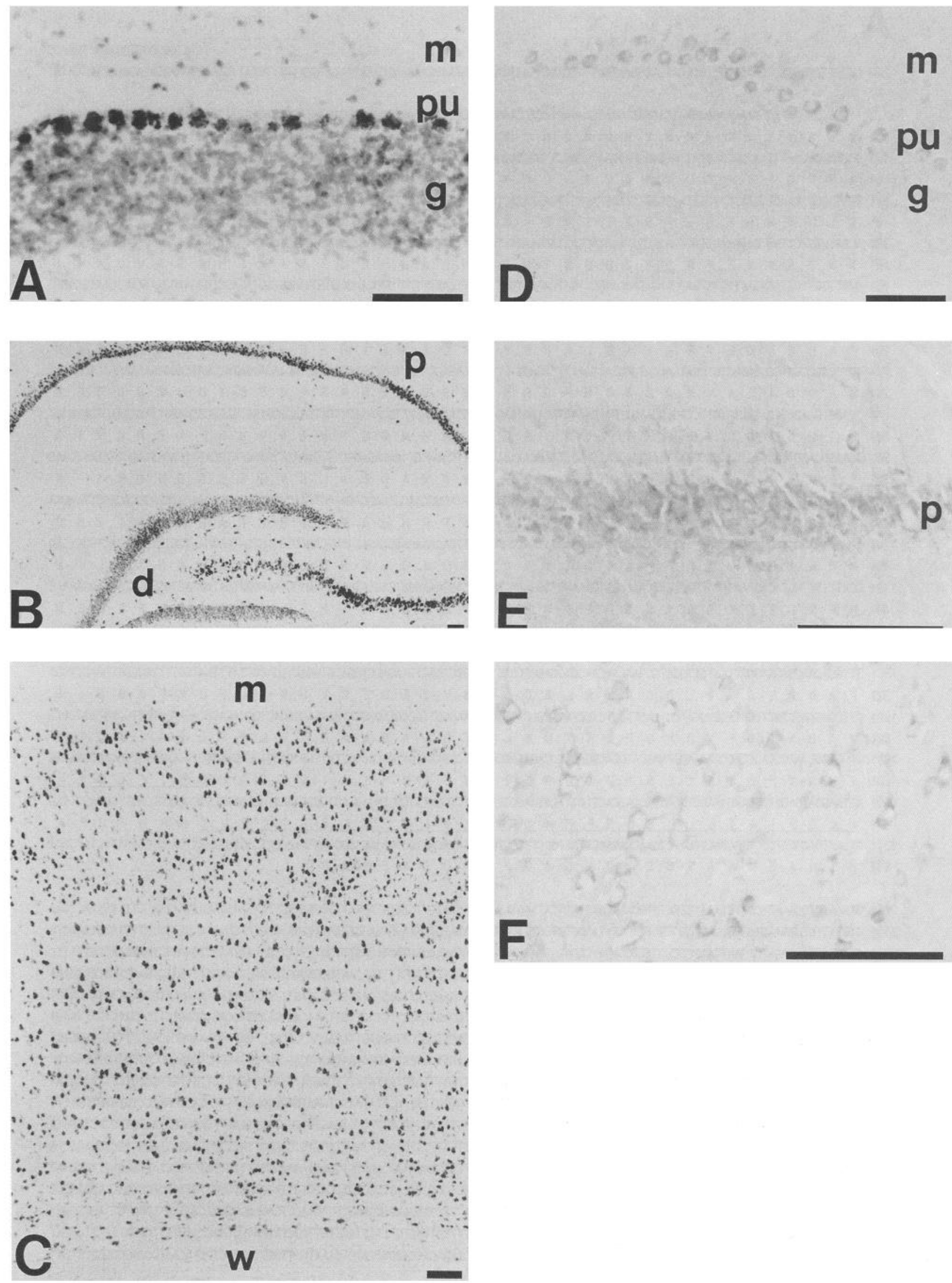
1 ATGTCACAGTATACAGAAAAAGAACCATCAGTAATGGATCAAGACTCCAGCAAGGCTGCGTGGCCTAGAGCAGCAGGAGGATACCAGACGATTACAGGCAGGAGGTACGGAGGGGGCAT

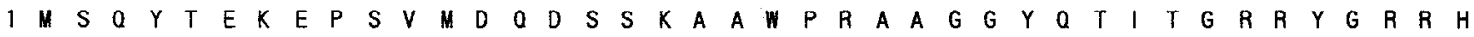
121 GCGTATGTCAGTTTTAAGCCATGTATGACCAGGCATGAACGGAGCTTGGGTCGGGCTGGCGATGACTATGAGGTTTGGAACTGGATGACGTTGCCAAGGAAAACACCGCAGGTTCCAGT 41 A Y V V S F K P C M T R H E R S L G R A G D D Y 241 TCATTGGATCAAGTCCATCCTTCTIACCCAGTGAAACTACAGTTGAAAAAAGTGAAACAGAAATTCCTACTTGTGGTCCAGCACTGAATCAAAGCACGGAGAGCAACCCATCCGTTGCC $81 S L D$ O V H P S L P S E T T V E K S E T E I P T C G P A L N O S T E S N P S V A 361 ACAGTGTGTCATAGTGAGGAaGTCAGGGAGACCTTAGACAGCAGTACGAATCTTCAGAATCACGCTGAGAGAGAGTGTACGCCAGCAGTTTGTAATGCCTCAAGTGTCCAGAATGGAATT 121 T $V$ C H S E E V R E T L D S S T $N$ L O $N$ H A E 481 GTGTGGTTCATACTGACTCTTATGATCCAGACAGCAAGCATGATGAGAATGACTCTCTTCAACTITGTGCCCAAGCTGTGGAAGGTGGTAGACGTCAGAAGGTATTAGGCAATGCAGTC 161 V L V H T D S Y D P D S K H D E N D S L O L C C A O A A V V E G G R R A K $K$ V L G 601 TITGAGCTGGAAAATGGAGAGGTAGAGAGATATGCTGATCTGTGTCCCTCAGTTCCCTCTCTCAGTGGTGAAATAAGGGAGGAGTCTGAAGAGCTAGGTTCAGCACTCTTAGAGAAAAAT 201 F E L E N G E V E R Y A D L C P S V P S L S G E I R E E S E E L G S A L L E K N 721 TCTGCTGGCGATGCGGAGGCTGTCCATCAGGATGGGCAGGAATTCAGAGGTCTTCTGAAGACGGCATTGTTAGAAAGAGGCGACAAGATGATAGCGATCAGGGAaGACAGACAGAAAAT

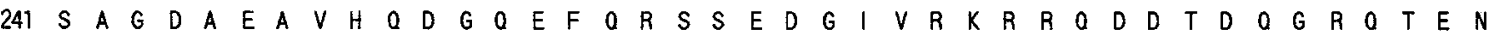
841 TCAACTGAGGATGCAGACTGTGTTCCAGGCCATGTGGACAAAATACTAGTGAGAGAGCCAATCACCATGGAAGTTCTCCTGAACAGGTAGTGAGGCCCAAAGTTAGAAAAGTGATCAGT 281 S T E D A D C V P P G H V E O N T S E R A N H H G S S P E O V V V R P $\quad K \quad V \quad R \quad K \quad V \quad I S$ 961 TCAAGCCAGGTGGACCAAGAGAGCGGTTTTAATAGGCACGAGGCTAAGCAAAGAAGTGTTCAGAGGTGGAGAGAGGCTCTGGAAGTTGAGGAATGCAGTTCAGATGACCCTATAATCAAG 321 S S O V D O E S G F N R H E A K O R S V O R W R E A L E V E E C S S 1081 TGTGACGATTATGATGGAGACCATGACTGCATGTTCCTAACCCCATCCTACTCAAGAGTTACGCCAAGGGAAGCAGAACGTCACCGTGCGACAGCAGAAAATGGAGCCACAGCTTCAGGA

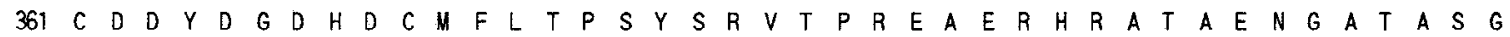
1201 AGGCAAGAGGCTCGGGAAAATGCCTITIGGATGCCTGTGGAGAGTATTACCAGCTCTTTGACAAAGACGAAGACAGTTCAGAGTGCAGTGATGGGGATGGTCTGCTTCTCTGCCTCAC 401 R O E A R E N A F W N A C G E Y Y O L F D K D E D S S S E C S D $G$ E W S A S L P H 1321 CGATITCTGGCACAGAAAAAGACCAGTCCTCAAGCGATGAAAGCTGGGAAACTCTGCCAGGAAAAGATGAGAATGAACCTGAGCTACAGAGTGATAGTAGTGGCCCTGAGGAAGAAAAC 441 R F S G T E K D O S S S D E S W E T L P G K D E N E P E L O S D S S G P E E E N 1441 CAAGAATTGTTCTTCAGGAGGGAGAACAGACGTCCTIGGAGGAGGGGGAGATTCCCTGGTTACAGTACAATGAGGTCAATGAGAGCAGCAGCGATGAAGGGAACGAGCCTGCCAATGAG

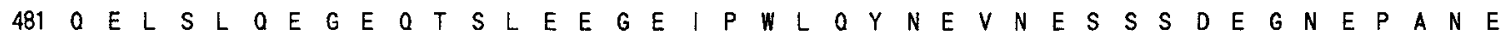
1561 TITGCACAACCAGAAGCTTTCATGTTGGATGGGAACAACAACCTGGAGGACGACTCGAGCGTGAGTGAAGACCTGGATGTGGACTGGAGCCTATTTGATGGTTTGGCGATGGACTTGGT $521 F A O P E A F M L D G N N N L E D D S S V S E D L D V D W S L F D G F A B G$ 1681 GTTGCTGAAGCTATTTCCTACGTGGATCCTCAGTTCCTCACCTACATGGCACTAGAAGAACGCTTAGCCCAGGCTATGGAGACTGCACTGGCACACTTAGAGTCTCTTGCTGTAGACGTT 561 V A E A I S Y V D P O F 1801 GAGGTGGCTAACCCACCTGCCAGTAAGGAAAGCATCGACGGACTTCCAGAAACCCTTGTCCTAGAAGATCACACCGCTATTGGTCAGGAGCAGTGCTGTCCCATCTGCTGCAGTGAGTAC 601 E V A N P P A S K E S I D G L P E T L V L E D H T A I G O E 1921 ATTAAGGATGACATCGCAACAGAGCTGCCCTGCCATCACTTCTTTCATAAGCCTTGTGTCTCCATTTGGCTACAGAAGTCCGGAACGTGCCCTGTGTGCCGCCGCCACTTCCCACCTGCA $6411 K D D$ I A T E L P C H H F F H K P C V S I W L Q K S G T C P V C R R H F P P A 2041 GTGATTGACGCATCTGCAGCTGCTTCCTCTGAACCAGACCTTGATGCCTCGCCTGCAAACGACAATGCTGAGGAAGCCCCGTAAGCCGTCACGGGGAAATGAGATCGAAATTCTATCACA 681 V I D A S A A A S S E P D L D A S P A N D N A E E A P *

2161 GTAAATCTGCAAATTCCTTCTAAATCTGATGTGCAAATAATTATATATAAATATATTTAAAATGCTCTATATAGTATATGCCGTAGTTTAGAAAGAGAATATTAACCTTTCTAAACTGAA 2401 CTGTTTGTCTGAAGTGCTGCCACTAAGAGATCAGAATTAAGCTCTCCTITCCACATCAGATGTGAAAGGAGAGCTTAATTCTGATCTCTGTGGCATACGTTICTGTTITGTTGAAGTG 2521 CTECCACTAAGAGATCAGAATTAAGCTCTCCTTICCACATCAGATGTGAAAACTGTGATCACAACAGTAGTACAGTTGGTTCATGGAAATAAACTGAATICTAAAGCATGCTTTTTC 2641 ACTEGTCCCTTTGCTTTGGTACTTCGAGACCTCTIGGTTATATAACACTGAGGTIAAGATTAAAGCTTTCAGAATGCCAGGCAAAGACTAGAGTTTGACCCGAACACACACACAAA 2761 ATAAAAAAATAAAAAATAAATTACATCTTAGATGTAAACTTCCTGAAACTGTCATGTAATAAACTATTCAGTGAACGTTGGATGTTAAAGGCTAGTAAAGCATGTGAATTATCTGATGT 2881 GCTTCATGCTCGGCACAGTCTCATGAGCTTGGCCTATGAAACACTGTCTAAGCCCTCATGCAGTCTGCTTCTACTTGTTAAACACTGAAGGTCCAGACCAGTCTTGGCATCTGATTAAGA 3001 AATTGGATGTAGTTAGCTAAGGTAGTTTGGTTCTACTTIAGGAGATCTGAAGATTTGCACATGGCCATGTCTGTTACAGCATCACCCCAGATTAGAGAGGCACAGCTTTTAGGTGGTCA 3121 CACGAGTAGGCAAGTCTGTGCAGACGCTGGTGTGATAGGTAGCTTACAGGTGAGCCCTGACATCAGCACAGGGACAACGGCTCAGCAGGCCCAGCACTGGAGCCCATCCGCGTGCACATC 3241 TACCTGCCCTGCTCATCCAGTICGGGATATTCTATAGCTTCCCAAATCAGCTTCATCTGATITGTGTAATATATCTGAGTATTATAGTCTTCTTITTCTCCAGTCTIAAAAATAA 3361 ATGAATTTCACTGTTGGCACATTTGAGGCTTAAATATAAGAAACCTAACACTTGCATTCTGATTTTGCATATATTGTAAATGTGGCTGGTATTTACAGCGAATCCTGTGTGTCCTTTT 3481 ATGGGTAAAACAAAAGTGAACATTGCATGCAAGTAATGTGGTGATTGTAATTIAGGGTTTTCTGGGCTTCTGTGACTGTGGATGCTTAAATTCAGGCCTTAATGTTGCTCTAGCTA 3721 AGCATCAGTTCCCATGTGTGCCGTGCGGATTGTGAGCCGTGTGGTTGCTTGGTTGGTTTCTTTATGTACTTGATTAGCTGTGGCACTTACTGAGTAAACTTACGTTGCTGCAGACTG 3841 CTGTGTAACAAGCCACGTTTIGTGTTAGTCAGTATTACACACGGGACCTTGTTTATTCTTCTAGATAGCAGCTGTCCCAAAGAAAATATTTCTCTTGCCTATTAAGATTAGCTAT 3961 TATCTGCCAGTIGTTAAGGGGTTGGTTCCAAACTCAACCAGAGTTGAACGTAAGAAAGCTGCTGTACTCTTGCTGTCCATCTGTTACGTCCTCCGTTGTTGGCTCCTGACTACGTACCC 4081 ACGGCTGCTGAAGGAGACTTGTTTAATTTGTTTAAAAAGGAAAATGAAGTTTTAGGACTTTGATGGTGGGGAAGCTGACAAGTTCAGACCCCAGTCTGTCATTTGCTCTTAGCTTGGA 4321 AACATTTTCTIATTTCTTGTAATATGAATGCCGATATTAAAGTTGACTCACTTGGGTTCTTTGTGTTCTTAGTTGTTATCTCTAAGCCTAACTAACTTTTAAGATTATTTGTGAT 4441 ATGGATTTATATAAGCTGTTAAATATATATGAGCTGTTAAAATGGAATGCAAGGTTTCCAAAGACCAGGTCTAACTGTAATGATTGGTITTGTTCTACAATCCCAGCCCGGCATITT 4561 CCGTGTAAATCATAAACAATAAACAGGATATACTCAGTGTTCATTTCTAAAAAAAAAA (4618) 


\section{B}

\begin{tabular}{|c|c|c|}
\hline neuroda & $1(629-678)$ & QEQC\%PI/CSEYIKD \\
\hline goliath & $(122-171)$ & DSDC \%AIYIEAYKPT \\
\hline $43 K$ & $(252-400)$ & MELTSGIYGESIGDQ \\
\hline PET3 & $(832-889)$ & PGKSWDF $/$ GKFLQI \\
\hline PET5 & $(925-977)$ & KNQT FM\%RLTLD \\
\hline CELG & $(48-117)$ & EDAT\%A IYLDNLQNN ( 20 \\
\hline FAR1 & $(147-206)$ & IGEK\%LI EESISSTFT \\
\hline & & $\begin{array}{lrl}\star & \# \star & \# \\
1 & 2 & \end{array}$ \\
\hline RING-1 & 12 finger & C $\mathrm{C}$ \\
\hline
\end{tabular}

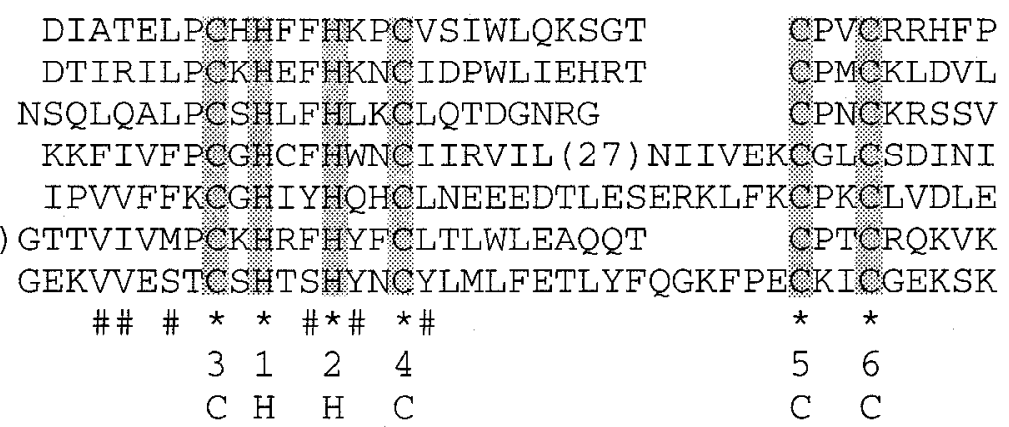

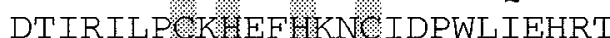
NSQLQALPYSILFYLK KLQTDGNRG

KKFIVFPOGTCF WNNIIRVIL (27) NIIVEKOGLSSDINI

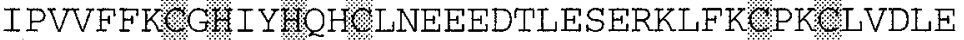
GTTVIVMPEK K IRF UYYTLTLWLEAOQT
EKIVGEKSK

$\begin{array}{ll}5 & 6 \\ C & C\end{array}$

Figure 4. A, Nucleotide and deduced amino acid sequence of the Neurodap1 gene. Nucleotide residues are numbered relative to the ATG that initiates the long open reading frame. The nucleotide and protein data reported in this figure have been submitted to DDBJ and assigned the accession number D32249. The RING-H2-finger motif is indicated by a solid line. B, Sequence alignment of the RING-H2-finger family. The metal binding ligands, which are absolutely conserved between the family members, are indicated by asterisks, as are the positions of conserved hydrophobic residues indicated by \#. The numbering (1-6 and 1-2) below each conserved Cys and His refers to the potential metal binding ligands $\mathrm{C} 1-$ $\mathrm{C} 6$ and $\mathrm{H} 1-\mathrm{H} 2$, respectively. The numbering in parentheses refers to the protein sequence (see text for reference to each sequence).

Neurodapl protein. A $1.2 \mathrm{kbp}$ cDNA fragment was amplified by PCR with oligomers $\mathbf{E}$ and $\mathbf{F}$ (5'-GGAGATCTGGGAAACTCTGCCAGGAAA-3' and 5'-GGGAATTCTGATCTCTTAGTGCAGC-3', respectively) using pfull223 as a template. The PCR product was digested with both BglII (TAKARA, Kyoto Japan) and EcoRI (TAKARA), and ligated into BamHI-EcoRI site of the pGEX-3X vector (Pharmacia, Uppsala, Sweden). The plasmid thus obtained directed the synthesis of a GST-fused protein carrying a carboxy-terminal portion of Neurodap1 (corresponding to amino acid residues 456-707 in Fig. 4A). This GSTNeurodap1 fusion protein was produced in $E$. coli with IPTG induction and affinity-purified with glutathione-sepharose $4 \mathrm{~B}$ beads as instructed by the supplier of the vector.

Antibodies against the GST-Neurodapl fusion protein were raised in New Zealand White rabbits and purified on a GST-Neurodap1 protein affinity column by conventional procedures.

Immunoblotting analysis. Cell extracts for immunoblots were prepared using a glass homogenizer, and proteins thus obtained were analyzed by SDS-polyacrylamide gel electrophoresis. Immunoblotting analyses were conducted with anti-rabbit IgG tagged with alkaline phosphatase (Promega) as previously described (Towbin et al., 1979).

Immunohistochemistry. The animals were perfused transcardially with $4 \%$ paraformaldehyde in PBS ( $\mathrm{pH} \mathrm{7.4)}$ under pentobarbital anesthesia, and their brains were further immersed in the same fixative for $4 \mathrm{hr}$. Four-micrometer-thick cryostat sections of the fixed brain were stained with the purified antibody (1:3500 dilution) by ABC method (Hsu et al., 1981) essentially as described previously (Miyake and Kitamura, 1992).

For electron microscopic immunohistochemistry, $60-\mu$ m-thick slices of the fixed brain were cut with Microslicer (Dosaka EM, Kyoto, Japan), and the slices were stained with the antibody (1:3500 dilution) and were flat-embedded in epoxy resin, as described previously (Miyake and Kitamura, 1992). One-micrometer-thick semithin sections and ultrathin sections of the resin-embedded tissue were observed under a light microscope (Nikon Optiphoto, Nikon, Tokyo, Japan) and an electron microscope (JEOL 100 CX II, JEOL; Tokyo, Japan), respectively.

Miscellaneous. Oligonucleotides were synthesized with a Pharmacia Gene Assembler Plus DNA synthesizer. PCR was routinely carried out with AmpliTaq DNA polymerase (Perkin-Elmer-Cetus, Norwalk, CT) and a DNA thermal cycler (Perkin-Elmer-Cetus) using the following thermal cycling conditions: denaturation at $94^{\circ} \mathrm{C}$ for $30 \mathrm{sec}$, annealing at $55^{\circ} \mathrm{C}$ for $1 \mathrm{~min}$, extension at $72^{\circ} \mathrm{C}$ for $30 \mathrm{sec}$, last extension at $72^{\circ} \mathrm{C}$ for 5 min; $30-50$ cycles. Rat multiple tissue Northern blot was purchased from Clontech Laboratories (Palo Alto, CA) and used according to the supplier's instruction.

\section{Results}

Subtractive/differential screening of the cDNA library

Subtractive/differential screening was performed to identify genes that were transcriptionally regulated $1 \mathrm{~d}$ after facial nerve axotomy. Because it is difficult to obtain a large amount of RNA from the facial nuclei (about $1.5 \mathrm{mg} /$ facial nucleus), the subtractive/differential screening was performed by using the directional cDNA libraries once constructed from the operated or unoperated facial nucleus as sources of ss cDNAs and driver biotinylated RNAs.

cDNA clones up- or downregulated by the axotomy were enriched by subtractive hybridization and the clones in the up- or downregulated cDNA-enriched library were subjected to cDNA insert amplification by PCR. The differential screening of these amplified DNAs was performed by dot hybridization using ${ }^{32} \mathrm{P}-$ labeled cDNA probe which was generated from mRNA of the operated or unoperated facial nucleus. By using these procedures, we isolated several candidate cDNAs which were transcriptionally induced or repressed in the facial nucleus following axotomy. For excluding incorrectly selected clones as artifacts, modulation of the cxpression levels of these candidate genes was further examined by in situ hybridization, although some genes could not be verified as an axotomy-associated gene by this method probably because of low sensitivity of in situ hybridization. Clones successfully confirmed as those carrying axotomyassociated cDNAs were partially sequenced, and the sequences were routinely subjected to homology search against the GenBank/EMBL/DDBJ DNA sequence dalabases. Thus, finally we could isolate nine cDNA clones, which were induced by axotomy, from the upregulated cDNA-enriched library containing 3000 clones. Nucleic acid homology search revealed that seven of them are already known, while the remaining two cDNAs are novel unknown genes. The seven known cDNAs encode the following proteins: GAP43, $\alpha$-tubulin, $\alpha$-internexin (Fliegner et al., 1990), SCG-10 (Okazaki et al., 1993), ubiquitin (Finch et al., 1990), MHC class I RT1 Aa $\alpha$-chain (Rada et al., 1990), and cathepsin S (Petanceska and Devi, 1992). The cDNA clones encoding GAP43 and $\alpha$-tubulin, which were previously reported to be upregulated in the facial nucleus after axotomy (Basi et al., 1987; Miller et al., 1989), were actually found in the seven known cDNAs thus isolated by this screening method. This observation indicated that the screening system worked as we expected.

In a similar manner, we also screened the down-regulated cDNA-enriched library (about 2000 cDNA clones) and isolated one clone carrying a novel, axotomy-suppressed cDNA. Since this cDNA, named Neurodapl, was found to encode a polypep- 
tide with a characteristic sequence motif, RING-H2, as described below, it might be possible to examine the function of the $\mathrm{Neu}$ rodapl-encoded product (Neurodap1) based on this sequence motif. In this study, we focus on characterization of Neurodapl and its product, Neurodap1.

\section{Expression of Neurodap1 in the rat brain}

RNA blotting analysis revealed that the brain is the most abundant in Neurodapl mRNA among the tissues examined (brain, heart, skeletal muscle, spleen, lung, liver, kidney, and testis), whereas the heart and skeletal muscle also contained very small but detectable amounts of this mRNA. Thus, we next focus on the detailed distribution of Neurodap1 mRNA in the brain.

On in situ hybridization the signals for mRNA of Neurodap1 were observed exclusively on the perikaryal cytoplasm of nerve cells, especially on that of large-sized nerve cells such as pyramidal cells in the cerebral cortex or hippocampus, Purkinje cells and those in the brainstem (Figs. 1, 2, 3A-C). These signals were considered to be specific, because a labeled sense probe did not give any signals under the same hybridization/washing conditions (data not shown). Weaker signals were detected on the granule cells of the hippocampal dentate gyrus. No signal for Neurodap $1 \mathrm{mRNA}$ was detected on glial cells at any regions of rat brains.

Strong hybridization signals for mRNA of Neurodapl were observed on the large nerve cells of the facial nuclei of the unoperated (right) side, while the signals were markedly decreased on the operated (left) side, and remained at about half levcl of those on the unoperated (right) side at $7 \mathrm{~d}$ after axotomy (Figs. 1, 2B). This low level expression still continued $14 \mathrm{~d}$ after axotomy (Fig. $2 C$ ). The level of hybridization signals on the nerve cells other than the operated facial nucleus was not affected by the facial nerve axotomy.

\section{Sequence analysis}

Since a single $4.8 \mathrm{kbp}$ band was detected in the rat whole brain mRNA using the first Neurodap1 cDNA clone $(2.2 \mathrm{kbp})$ as a probe by RNA blotting analysis, the first Neurodapl cDNA clone seemed to be a partial one for Neurodapl cDNA. A fulllength cDNA of Neurodapl was eventually isolated from the unoperated facial nucleus cDNA library by colony hybridization technique. The nucleic acid sequence of Neurodapl cDNA allowed us to predict the presence of an open reading frame consisting of 707 amino acid residues (Fig. $4 A$ ). The cDNA sequence showed no significant similarity with sequences except for human EST00844 and mouse Tsg163X in the databases available (Hoog, 1991; Adams et al., 1992). Since neither obvious transmembrane domains nor $\mathrm{N}$-terminal signal sequence was identified, this predicted protein seemed to be a cytoplasmic protein.

Protein sequence motif search indicated that the region near the carboxy terminus of Neurodap1 carries a defined sequence motif, the RING-H2-finger motif (Freemont, 1993), which is found in the Drosophila protein called goliath (Bouchard and Côté, 1993) and some RING-finger proteins. The RING-H2-finger motif is $\mathrm{Cys}_{1}-\mathrm{X}-\mathrm{X}$ (hydrophobic)-Cys $2-\mathrm{X}(12-35)-\mathrm{Cys}_{3}-\mathrm{X}$ $\mathrm{His}_{1}-\mathrm{X}-\mathrm{X}$ (hydrophobic)-His $-\mathrm{X}$ (hydrophobic)-X-Cys $\mathrm{S}_{4} \mathrm{X}$ (8-39)$\mathrm{Cys}_{5}-\mathrm{X}-\mathrm{X}-\mathrm{Cys}_{6}$, where $\mathrm{X}$ refers to an arbitrary amino acid residue (Freemont, 1993). A portion of the carboxy-terminal region of Neurodap1 was compared with the RING-H2-finger motif in goliath (Bouchard and Côté, 1993), 43-kDa postsynaptic membrane protein (43K) (Scotland et al., 1993), PET3/Vps18 (Pres- ton et al., 1991; Robinson et al., 1991), PET5/Vps11/End1 (Dulic and Riezman, 1989), CELG (Freemont, 1993), and FAR1 (Chang and Herskowitz, 1990) (Fig. 4B). This comparison suggested that the carboxy-terminal part of Neurodap 1 has the same structure as defined by the RING-H2-finger motif.

\section{Neurodap1 protein and its distribution in the rat brain}

In vitro transcription-translation coupling assay was performed using the full-length cDNA of Neurodapl as a template. Although the product gave multiple bands on SDS-polyacrylamide gel, the largest polypeptide was supposed to be the expected product of this cDNA, while the small polypeptides (about 46$60 \mathrm{kDa}$ ) were assumed to be spurious products. The molecular mass of in vitro synthesized Neurodap1 was estimated to be about $140 \mathrm{kDa}$ by SDS-polyacrylamide electrophoresis (Fig. $5 B$ ). This value was larger than the expected one deduced from the primary structure (about $80 \mathrm{kDa}$ ), whereas no posttranslational modification would occur in this in vitro system. The possibility of error in the identification of the open-reading frame was excluded by the following observation based on the fact that unique EcoRI and HindIII sites are located after and before the identified termination codon, respectively: the removal of 3'noncoding region by EcoRI digestion did not change the apparent molecular mass of the in vitro product, while the loss of the identified termination codon by HindIII digestion resulted in generation of a truncated product with greatly reduced efficiency (Fig. 5A,B). Thus, the discrepancy between the expected and observed molecular masses might be explained by anomaly of protein migration rates on SDS-polyacrylamide gel (Ohara and Teraoka, 1987).

A cDNA fragment encoding amino acid sequence of about one third of the carboxy-terminal portion of Neurodap1 (amino acid residues 456-707 in Fig. 4A) was fused to GST gene, and the GST-Neurodapl fused protein was expressed in $E$. coli using a fusion protein production system. The GST-Neurodap1 fusion protein purified on a glutathione resin appeared as a single band on SDS-polyacrylamide gel electrophoresis (Fig. 5C). Using this purified GST-Neurodap 1 fusion protein, antiserum was raised in rabbits, and purified on a GST-Neurodap1 fusion protein affinity column. The purified antibody against the GST-Neurodap1 fusion protein, thus obtained, reacted specifically with the bacterial recombinant GST-Neurodap1 protein (Fig. 5D). The specificity of the antibody against Neurodap I was confirmed by the following lines of evidence. First, the distribution of the brain cells immunostained by this antibody was identical to that of the mRNA-positive cells observed on in situ hybridization, as described below. The signals for Neurodapl mRNA and its protein, Neurodap1, were observed on nerve cells, but not on glial cells. Second, this antibody mainly stained a single protein band of the brain extract on immunoblots (Fig. $5 D$ ), and this band comigrated with in vitro synthesized Neurodap1 (Fig. 5B). Third, this antibody immunoprecipitated not only the bacterially expressed GST-Neurodapl fusion protein but also Neurodapl itself obtained from the rat brain extract (data not shown).

Immunohistochemistry using the purified antibody against Neurodap1 revealed that the distribution of Neurodap1-positive cells was essentially the same as that of its mRNA shown by in situ hybridization (Fig. 3). Immunohistochemistry on 1- $\mu \mathrm{m}-$ thick sections revealed that Neurodap1 was distributed in the cytoplasm forming a characteristic punctate pattern (Fig. 6). The immunoreactivity for Neurodap1 decreased significantly after axotomy (Fig. 6B). 
A

\section{open reading frame}

\section{full}

\section{EcoRI}

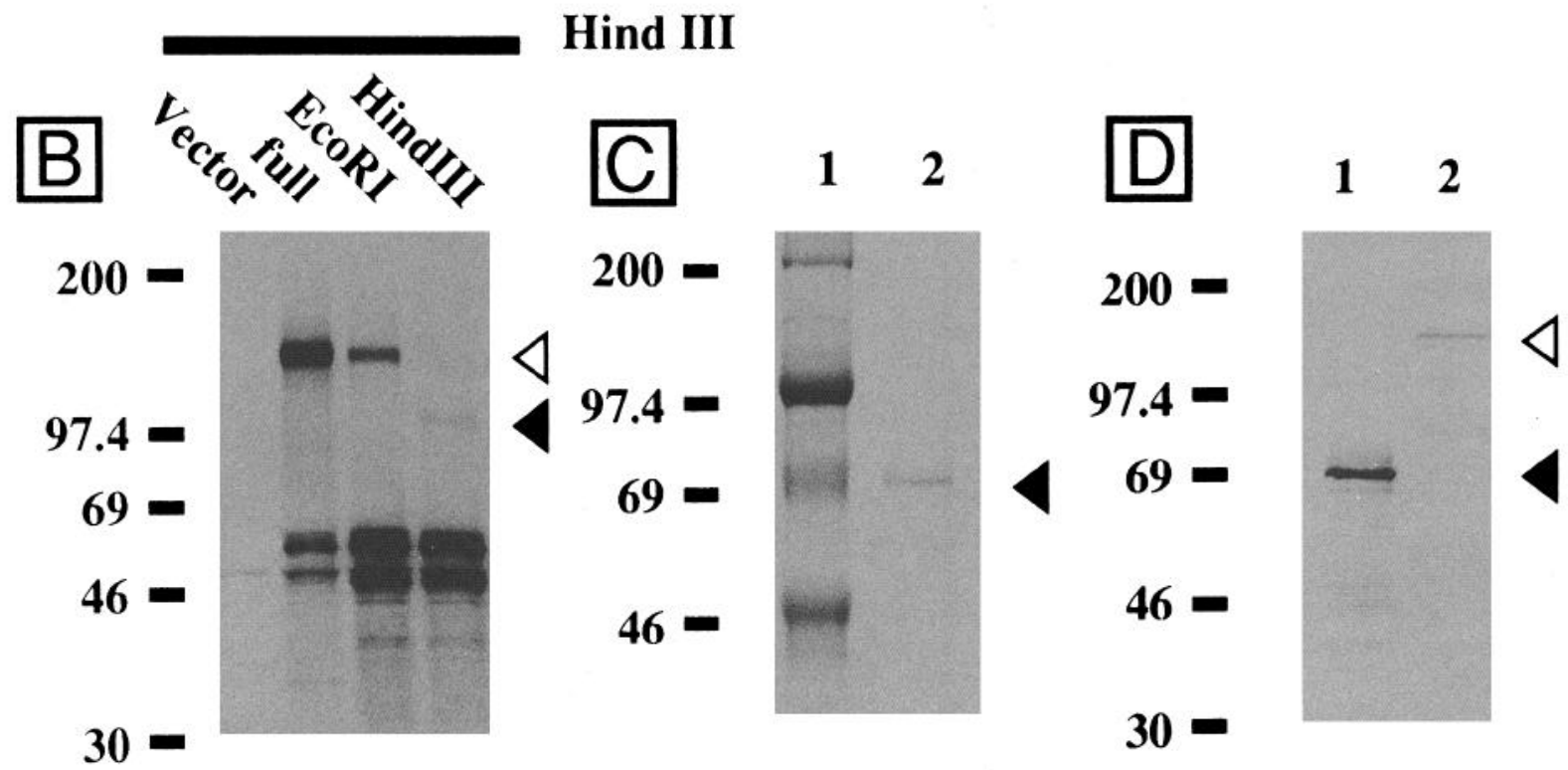

(kDa)

(kDa)

(kDa)

Figure 5. A, Summary of various sizes of templates for in vitro transcription-translation assay. Solid bars indicate the full-size and truncated cDNA of Neurodap1 gene. Open box indicates the open reading frame of Neurodap1 cDNA. B. Identification of Neurodap1 protein by in vitro transcription-translation assay. In vitro transcription-translation coupling assays were performed using pBluescript SK(-) (Vector), pfull223 (full), the EcoRI digested pfull223 (EcoRI), and the HindIII digested pfull223 (Hind III) as a template. Aliquots of each sample were analyzed by electrophoresis on $4-20 \%$ polyacrylamide gel in the presence of SDS. The open triangle indicates the position of Neurodap1 protein. The solid triangle indicates the position of truncated Neurodap 1 protein. $C$, Coomassie brilliant blue staining. The GST-Neurodap1 fusion protein was affinitypurified with glutathione-sepharose 4B beads. One microgram of the purified GST-Neurodapl fusion protein was analyzed by $10 \%$ SDS-polyacrylamide gel electrophoresis (lane 2). Lane 1, molecular weight makers. D, Immunoblotting analysis using the affinity-purified anti-Neurodap1 antibody. Lane $1,0.1 \mu \mathrm{g}$ of the purified GST-Neurodap1 fusion protein. Lane 2, $75 \mu \mathrm{g}$ of cytoplasmic fraction from the rat hippocampus. Numbers on the left of the figures indicate positions of molecular weight markers.
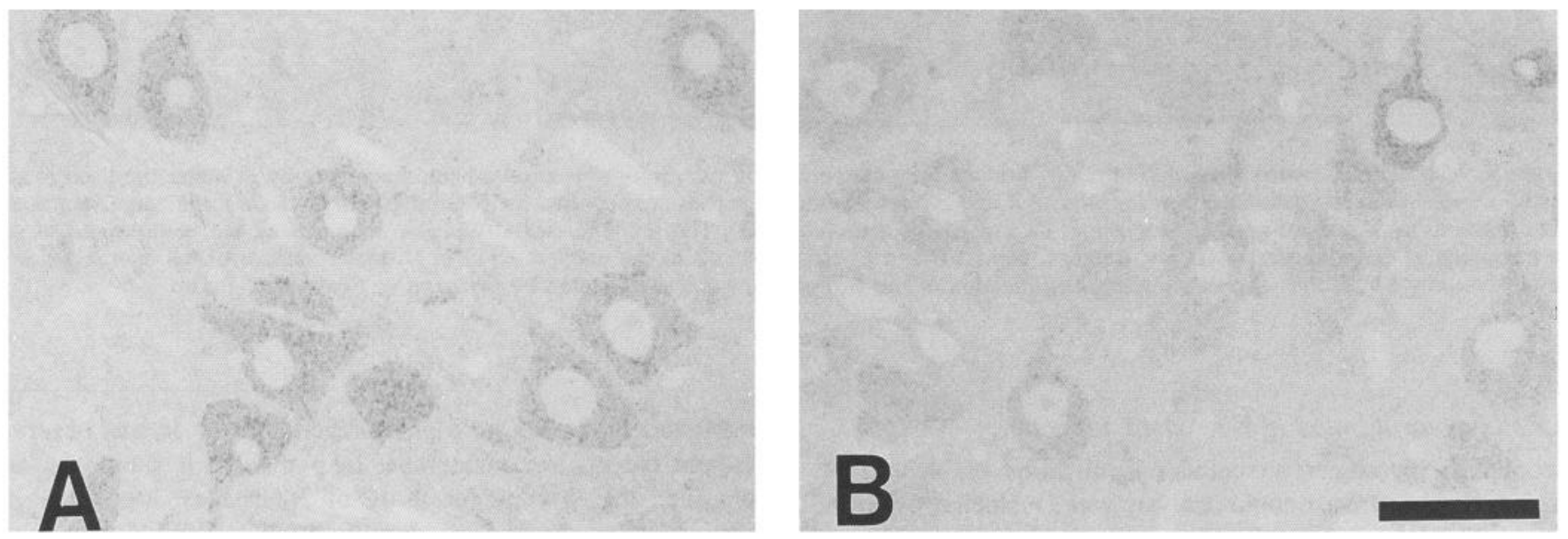

Figure 6. Immunohistochemical analysis on $1 \mu \mathrm{m}$ thick sections shows the characteristic punctuate distribution of Neurodap1 protein in the cell body of the facial motoneurons. The immunoreactivity is significantly decreased following axotomy $(B)$. $A$, Facial nucleus of the unoperated side; $B$, facial nucleus of the operated side. Nine days after axotomy. Scale bar, $50 \mu \mathrm{m}$. 

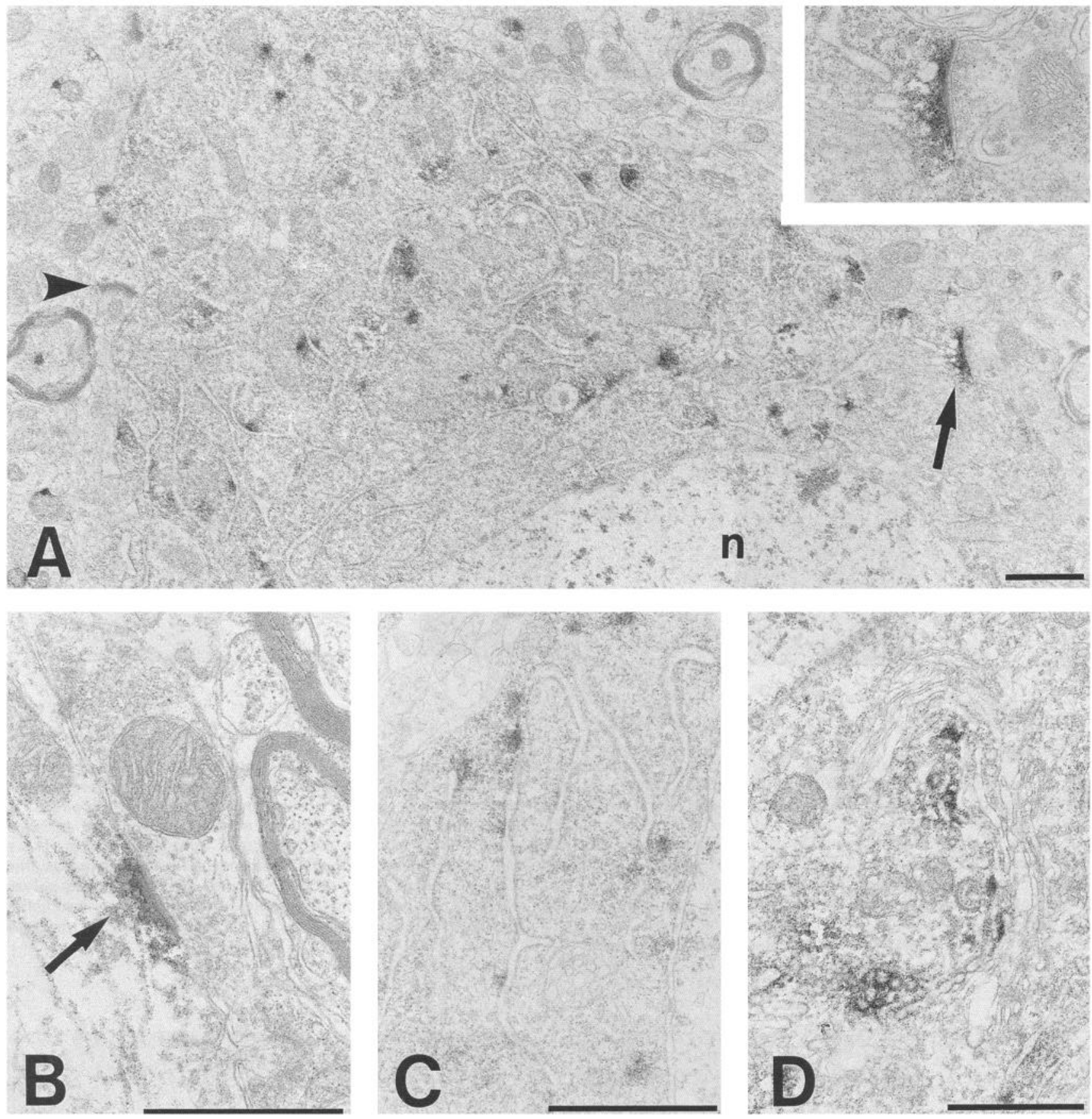

Figure 7. Subcellular localization of Neurodap1 protein by immunoelectron microscopy. Neurodap1-immunoreactivity exists at the postsynaptic density regions of axosomatic synapses (arrows in $A$ and $B$ ). Axospinous synapses are negative for Neurodap1 (arrowhead). Punctate Neurodap1immunoreactivity is present on the cytoplasmic face of ER of neurons $(A, C)$. The immunoreactivity is also seen around the vesicles and sacs of the trans-side of Golgi apparatus $(D)$. $A$, Cerebral cortex; $B$ and $C$, facial nucleus of the unoperated side; $D$, facial nucleus of the operated side $(9$ $\mathrm{d}$ after axotomy). Inset in $A$ shows a higher magnification of the axosomatic synapse indicated by arrow in $A$. Scale bars, $1 \mu \mathrm{m}$.

\section{Subcellular localization of Neurodap1 protein}

In order to investigate subcellular localization of Neurodap1, immunoelectron microscopic analysis was conducted using the same antibody. As shown in Figure $7 A$, Neurodap1 was found to be concentrated around endoplasmic reticulum (ER) and Golgi apparatus. Reaction product was detected on the cytoplasmic surface of ER, Golgi apparatus, some tiny vesicles and cell membrane, whereas no immunoreaction product was observed around the nuclear membrane. In particular, it should be emphasized that immunoreactivity of Neurodap1 was often observed in the postsynaptic density (PSD) region of axosomatic synapses (Fig. $7 A, B$ ): $35 \%$ of the PSDs of axosomatic synapses was decorated with Neurodap1 in the nerve cells of the facial nucleus, whereas most of the PSDs of axosomatic synapses in 
the cerebral cortex were associated with Neurodap1. This observation indicates that the association of Neurodap1 to PSD significantly depends on types of PSD.

After axotomy, no remarkable changes in the subcellular dis tribution pattern of Neurodapl were found by the electron microscopic immunohistochemistry. Although Neurodap1-immunoreactivity was generally decreased following axotomy, the immunoreactivity appeared to be slightly augmented around Golgi apparatus (Fig. 7D).

\section{Discussion}

Axonal injury elicits highly complex reactions involving nerve cells and glial cells. In this study, we identified some genes that responded to axonal injury. The cloning strategy we took, a subtractive/differential screening, worked well, since some previously identified axotomy-associated genes were obtained by this screening method without any a priori knowledge of them. The genes thus selected constitute a catalog of axotomy-associated genes, although the number of clones searched in this study might not be enough for making this catalog complete. Since we could demonstrate the feasibility to isolate axotomyassociated genes by this cloning/screening strategy, the next question is obviously how to clarify the functions of these axotomy-associated genes.

A possible answer to this question comes from protein sequence motifs found in the axotomy-associated proteins. Since there are more than 920 sequence motifs in PROSITE motif database, it might be possible to predict the function of a newly identified gene product from the protein sequence motif. As an example of studies in this line, we here focused on Neurodapl, since it contains a characteristic sequence motif known as the RING-H2-finger motif (Freemont, 1993). The RING-finger motif is a cysteine-rich amino acid sequence motif found in the sequence of the human ring1 gene (Luvering et al., 1993). The RING-H2-finger motif is closely related to the RING-finger motif, and Cys 4 in the RING-finger motif is replaced by His (Freemont, 1993). Although many RING-finger proteins are reported to have DNA-binding activity as in the case of zinc-finger proteins, most of RING-H2-finger proteins and a few of RINGfinger proteins were thought not to bind DNA (Freemont, 1993). In particular, a subfamily of RING- or RING-H2-finger motif proteins, which carries this sequence motif at their respective carboxy-terminal portion, is known to be associated with vacuoles or membrane: the yeast proteins PET3/Vps18p and PET5/ Vps11/END1 have been implicated in vacuolar biogenesis (Dulic and Riezman, 1989; Preston et al., 1991; Robinson et al., 1991), and 43K has been implicated in the clustering and aggregation of $\mathrm{ACh}$ receptors and is found to be associated with the plasma membrane (Scotland et al., 1993). From these observations, it has been suggested that the RING-H2 finger could form a protein-protein or a protein-lipid interacting domain. Since Neurodap 1 can be structurally categorized into this RING$\mathrm{H} 2$ finger protein subfamily, we expected that Neurodap1 was localized on membranes. In fact, the immunoelectron microscopic observation showed that Neurodap1 was associated with the cytosolic face of the membranes of ER and Golgi apparatus and, interestingly, with the postsynaptic region on the cytoplasmic membrane. Thus, the sequence motif successfully led us to discover of an interesting property of this protein, that is, the characteristic localization of Neurodap1 in the perikaryal cytoplasm.

The analysis of the subcellular localization of Neurodapl gave us some insight into its function: Neurodap1 is most likely to be linked to the secretory or protein sorting machinery. More importantly, Neurodap1 may play an crucial role at the postsynaptic regions of some types of axosomatic synapses, since this protein is specifically present in the postsynaptic region of axosomatic synapses of large-sized nerve cells and since its gene expression is downregulated in the condition such as axotomy of the facial nerve, where the number of axosomatic synapse decreases. In other words, Neurodap1 is mainly expressed in nerve cells whose cell bodies and axosomatic synapses are well developed. This might suggest that Neurodap1 plays a specific biological role at the postsynaptic region rather than a general one in the protein sorting machinery. While the function of Neurodapl seems to be related to that of PSD, Neurodap1 was not always associated with PSD as in the case of the facial motoneurons. Thus, Neurodap1 is dispensable for constructing PSD in some nerve cells. If one could specify the PSD types which always associate Neurodap1, it might give us a hint to describe the function of Neurodap1 in more details. Since PSD has drawn much attention from a viewpoint of its relationship to synaptic communication and plasticity (Siekevitz, 1985; Walsh and Kuruc, 1992), it would be interesting to examine whether the expression of Neurodapl is modulated by synaptic interactions following learning, developmental stages, and neurodegenerative conditions such as ischemia, kindling, and Alzheimer's disease.

\section{References}

Adams MD, Dubnic M, Kerlavage AR, Moreno R, Kelley JM, Utterback TR, Nagle JW, Fields C, Venter JC (1992) Sequence identification of 2,375 human brain genes. Nature 355:632-634.

Bairoch A (1991) PROSITE: a dictionary of sites and patterns in proteins. Nucleic Acids Res 19:2241-2245.

Basi GS, Jacobson RC, Virag I, Schilling J, Skene JHP (1987) Primary structure and transcriptional regulation of GAP-43, a protein associated with nerve growth. Cell 49:785-791.

Blinzinger K, Kreutzberg GW (1968) Displacement of synaptic terminals from regenerating motoneurons by microglia cells. Z Zellforsch Mikrosk Anat 85:145-157.

Bouchard ML, Côté S (1993) The Drosophila melanogaster developmental gene $g l$ encodes a variant zinc-finger-motif protein. Gene 125: 205-209.

Chang F, Herskowitz I (1990) Identification of a gene necessary for cell cycle arrest by a negative growth factor of yeast: FAR 1 is an inhibitor of a G1 cyclin, CLN2. Cell 63:999-1011.

Chiu AY, Chen EW, Loera S (1993) A motor neuron-specific epitope and the low-affinity nerve growth factor receptor display reciprocal patterns of expression during development, axotomy, and regeneration. J Comp Neurol 328:351-363.

Chomczynski P, Sacchi N (1987) Single-step method of RNA isolation by acid guanidinium thiocyanate-phenol-chloroform extraction. Anal Biochem 162:156-159.

Dulic V, Riezman H (1989) Characterization of the ENDI gene required for vacuole biogenesis and gluconeogenic growth of budding yeast. EMBO J 8:1349-1359.

Finch JS, Bonham K, Krieg P, Bowden GT (1990) Murine polyubiquitin mRNA sequence. Nucleic Acids Res 18:1907.

Fliegner KII, Ching GY, Liem RK (1990) The predicted amino acid sequence of $\alpha$-internexin is that of a novel neuronal intermediate filament protein. EMBO J 9:749-755.

Freemont PS (1993) The RING finger: a novel protein sequence motif related to the zinc finger. Ann NY Acad Sci 684:174-192.

Graeber MB, Kreutzberg GW (1986) Astrocytes increase in glial fibrillary acidic protein during retrograde changes of facial motor neurons. J Neurocytol 15:363-373.

Graeber MB, Kreutzberg GW (1988) Delayed astrocyte reaction following facial nerve axotomy. J Neurocytol 17:209-220.

Graeber MB, Tetzlaff W, Streit WJ, Kreutzberg GW (1988) Microglia cells but not astrocytes undergo mitosis following rat facial nerve axotomy. Neurosci Lett 85:317-321. 
Hoog C (1991) Isolation of a large number of novel mammalian genes by a differential cDNA library screening strategy. Nucleic Acids Res 19:6123-6127.

Hsu SM, Raine L, Fanger H (1981) Use of avidin-biotin-peroxidase complex $(\mathrm{ABC})$ in immunoperoxidase techniques: a comparison between $\mathrm{ABC}$ and unlabeled antibody (PAP) procedures. $\mathrm{J}$ Histochem Cytochem 29:577-580.

Kitamura T (1991) Gene expression of CNS intermediate filaments in the developmental stage and regeneration period. In: Functional neuroteratology of short-term exposure to drugs (Fujita T, Boer GJ, eds), pp 187-197. Tokyo: Teikyo UP.

Kitamura T, Fujita S (1985) Development, morphology and reaction of glial cells (II). Denshi-kenbikyou 19:193-199 [in Japanese].

Kitamura T, Watanabe S (1990) Intermediate filament gene expression in normal and retrograde degeneration of rat brains as visualized by in situ hybridization. Acta Histochem Cytochem 23:375-386.

Kitamura T, Watanabe S, Fujita S (1991) Gene expression of neuronal intermediate filament protein in normal and altered brains. Neuropathol [Suppl] 4:263-268.

Lovering R, Hanson IM, Borden KLB, Martin S, O'Reilly NJ, Evan GI, Rahman D, Pappin DJC., Trowsdale J, Freemont PS (1993) Identification and preliminary characterization of a protein motif related to the zinc finger. Proc Natl Acad Sci USA 90:2112-2116.

Miller FD, Tetzlaff W, Bisby MA, Fawcett JW, Milncr RJ (1989) Rapid induction of the major embryonic $\alpha$-tubulin mRNA, Ta1, during nerve regeneration in adult rats. J Neurosci 9:1452-1463.

Miyake T, Kilamura T (1992) Glutamine synthetase immunoreactivity in two types of mouse brain glial cells. Brain Res 586:53-60.

Nakayama M, Gahara Y, Kitamura T, Ohara O (1994) Distinctive four promoters collectively direct expression of brain-derived neurotrophic factor gene. Mol Brain Res 21:206-218.

Ohara O, Teraoka H (1987) Anomalous behavior of human leukocyte interferon subtypes on polyacrylamide gel electrophoresis in the presence of dodecyl sulfate. FEBS Lett 211:78-82.

Okazaki T, Yoshida BN, Avraham KB, Wang H, Wuenschell CW, Jenkins NA, Copeland NG, Anderson DJ, Mori N (1993) Molecular diversity of the SCG10/stathmin gene family in the mouse. Genomics 18:360-373.

Pearson, WR, Lipman DJ (1988) Improved tools for biological sequence comparison. Proc Natl Acad Sci USA 85:2444-2448.

Petanceska SS, Devi LA (1992) Sequence analysis, tissue distribution and expression of rat cathepsin S. J Biol Chem 267:26038-26043.

Preston RA, Manolson MF, Becherer K, Weidenhammer E, Kirkpatrick D, Wright R, Jones EW (1991) Isolation and characterization of PET3, a gene required for vacuolar biogenesis in Sacchromyces cerevisiae. Mol Cell Biol 11:5801-5812.
Rada C, Lorenzi R, Powis SJ, van den Bogaerde J, Parham P, Howard JC (1990) Concerted evolution of class I genes in the major histocompatibility complex of murine rodents. Proc Natl Acad Sci USA 87:2167-2171.

Robinson JS, Graham TR, Emr SD (1991) A putative zinc finger protein, Sacchromyces cerevisiae. Vps18p, affects late golgi function required for vacuolar protein sorting and efficient a-factor prohormone maturation. Mol Cell Biol 12:5813-5824.

Rubenstein JLR, Brice AEJ, Ciaranello RD, Denney D, Porteus MH, Usdin TB (1990) Subtractive hybridization system using singlestranded phagemids with directional inserts. Nucleic Acids Res 18: $4833-4842$.

Saika T, Senba E, Noguchi K, Sato M, Yoshida S, Kubo T, Matsunaga T, Tohyama M (1991) Effects of nerve crush and transection on mRNA levels for nerve growth factor receptor in the rat facial motoneurons. Mol Brain Res 9:157-160.

Scotland PB, Colledge M, Melnikova I, Dai Z, Froehner SC (1993) Clustering of the acetylcholine receptor by the $43-\mathrm{kD}$ protein: involvement of the zinc finger domain. J Cell Biol 123:719-728.

Siekevitz P (1985) The postsynaptic density: a possible role in longlasting effects in the central nervous system. Proc Natl Acad Sci USA 82:3494-3.

Solà C, García-Ladona FJ, Sarasa M, Mengod G, Probst A, Palacios G, Palacios JM (1993) BAPP gene expression is increased in the rat brain after motor neuron axotomy. Eur J Neurosci 5:795-808.

Springer JE, Robbins E, Gwag BJ, Lewis ME, Baldino F (1991) Nonradioactive detection of nerve growth factor receptor (NGFR) mRNA in rat brain using in situ hybridization histochemistry. J Histochem Cytochem 39:231-234.

Swaroop A, Xu J, Agarwal N, Weissman SM (1991) A simple and efficient cDNA library subtraction procedure: isolation of human retina-specific cDNA clones. Nucleic Acids Res 19:1954.

Tetzlaff W, Alexander SW, Miller FD, Bisby MA (1991) Response of facial and rubrospinal neurons to axotomy: changes in mRNA expression for cytoskeletal proteins and GAP-43. J Neurosci 11:25282544 .

Towbin HH, Staehelin T, Gordon J (1979) Electrophoretic transfer of protcins from polyacrylamide gels to nitrocellulose sheets: procedure and some applications. Proc Natl Acad Sci USA 76:4350-4354.

Walsh MJ, Kuruc N (1992) The postsynaptic density: constituent and associated proteins characterized by electrophoresis, immunoblotting, and peptide sequencing. J Neurochem 59:667-678.

Yu WhA (1989) Dissection of motor nuclei of trigeminal, facial, and hypoglossal nerves from fresh rat brain. In: A dissection and tissue culture manual of the nervous system (Shahar A, Vellis J, Vernadakis A, Haber B, eds), pp 30-39. New York: Liss. 